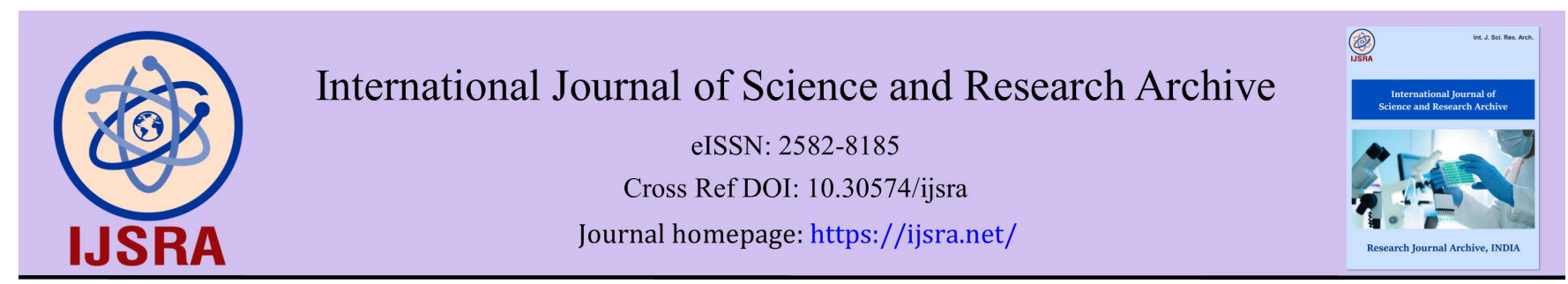

(RESEARCh ARTICLE)

\title{
Assessing the risk of heavy metals contamination in milk from Pakistan
}

\author{
ZH Shar ${ }^{1,}{ }^{*}$, OP Pirhot ${ }^{1}$, HH Shar ${ }^{2}$ and MK Channa ${ }^{3}$ \\ ${ }^{1}$ Dr. M.A Kazi Institute of Chemistry, University of Sindh, Jamshoro, Pakistan. \\ ${ }^{2}$ National Center of excellence in analytical chemistry, University of Sindh, Jamshoro, Pakistan. \\ ${ }^{3}$ Institute of Chemistry, Shah Abdul Latif University, Khairpur, Sindh, Pakistan.
}

International Journal of Science and Research Archive, 2021, 03(01), 107-113

Publication history: Received on 03 July 2021; revised on 18 August 2021; accepted on 20 August 2021

Article DOI: https://doi.org/10.30574/ijsra.2021.3.1.0114

\begin{abstract}
Milk is an essential component of human food, and natural source of many important elements. Besides essential elements it is also became a source of toxic metals due to heavy environmental pollution. In order to assess the essential metals (calcium) and toxic metals (cadmium and lead) in milk, sixty different fresh milk samples were analyzed by using atomic absorption spectroscopy (AAS). Accuracy and precession were checked by external standard addition method. Calcium was found in all samples with highest concentration $(24 \mu \mathrm{g} / \mathrm{L})$ in camel milk. Lead was found in all milk samples

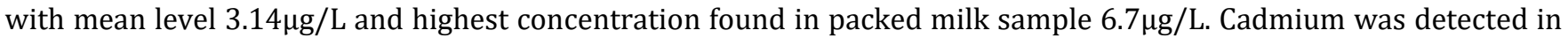
$33 \%$ of total samples analyzed with range of (1.1-3.1 $\mu \mathrm{g} / \mathrm{L})$. Results of this study will be helpful in setting the standards in one of the most consumed commodities in Pakistan.
\end{abstract}

Keywords: Toxic metals; Milk; Flame atomic absorption spectroscopy; Acid digestion

\section{Introduction}

Milk is an indispensible commodity of the human diet; provide essential nutrients needed for growth and development of the body. Milk is considered as a rich source of many micro and macro nutrients; but at the same time it has become a source of many toxic metals due to environmental pollution [1]. Occurrence of the toxic metals in milk could be considered as an important indicator of the hygienic quality of the milk [2,3]. Milk originated from different animals, have different nutrients profile so it is imperative to assess the essential and toxic heavy metals in milk originated from the different animal sources.

Milk is the most varied natural foodstuff in terms of its composition and contain more than twenty different essential trace elements needed for many physiological functions [4]. Deficiencies of these trace elements lead to many diseases; however, if present at higher levels, they may have a negative effect on human or animal health. Presence of these elements in milk depend on many factors including the stage of lactation, nutritional status of the animal, environmental and genetic factors, characteristic of the manufacturing practices and possible contamination from the equipment during processing [5].

Milk is considered as a rich source of calcium and essential for bone health along with potassium (K) and magnesium (Mg). Optimal Ca intake positively affects bone mass, ensuring adequate bone development in childhood and youth. Calcium is an essential for preventing osteoporosis[6, 7], It is also crucial for nerve conduction, muscles contraction, heart beat and blood coagulation, production of energy and maintenance of immune function. Calcium decreases the odds of getting colon and breast cancer, improves weight control and reduces the risk of developing kidney stones [8$11]$.

${ }^{*}$ Corresponding author: Zahid Hussain Shar

Dr. M.A Kazi Institute of Chemistry University of Sindh, Jamshoro, Pakistan.

Copyright $(2021$ Author(s) retain the copyright of this article. This article is published under the terms of the Creative Commons Attribution Liscense 4.0. 
Reports of milk contamination with heavy metals have received much attention recently. Heavy metal is a general term applied for metals and metalloids having density greater than $6 \mathrm{~g} / \mathrm{cm}^{3}$ [12]. One of the most problems associated with heavy metal is their ability to bio accumulate and poses greater risk when reached at the end of food chain [13-16]. Heavy metals gain entry into the milk mainly through cattle feed and drinking water (besides air) which in turn are contaminated from sewage sludge, artificial fertilizers, metals used in fungicidal agents, agricultural chemicals and wastewater from industries.[17]. The occurrence of Lead inhibits ferrochelatase, which leads to decrease red blood cell survival, decrease in the rate of globin synthesis and an inhibition of the heme synthesis [18, 19]. Cadmium has been implicated in osteoporosis with impaired general health, lung and kidney damage [20]. Long term chronic exposure to cadmium has been associated with anemia, osteomalacia and cardiovascular diseases especially hypertension [21-23]. Due to their toxicity, various countries have set up maximum regulatory limits for food products. see Table 1.

Pakistan is facing water shortage and use of sewage and industrial wastages for the growth of plants is the most common practice, which increase heavy metal accumulation in plants [24]. Heavy metals accumulation in plants leaves and vegetables have been reported from Pakistan [25-30]. These studies have suggested that the fodders grown with such soil and water will have higher heavy metals, and animal's rear on contaminated fodders will accumulate heavy metals in animal tissues and their milk.

Hyderabad city is located at the end of river Indus and most of the sewage water and industrial wastes directly goes into river water. Fodders grown on contaminated water used for rearing animal in this region likely to have higher heavy metal contamination $[31,32]$. Therefore, the present study was undertaken to assess the heavy metal residues in different milk samples. The result of this study will help to determine the potential toxic effects of heavy metals.

Table 1 Recommended levels/ safe intake of heavy metal

\begin{tabular}{|l|l|c|}
\hline Heavy metals & Allowable limit & Reference \\
\hline \multirow{2}{*}{ Cadmium } & $15-50 \mu \mathrm{g} /$ day adults & \multirow{2}{*}{} \\
\cline { 2 - 2 } & $2-25 \mu \mathrm{g} /$ day children & \multirow{2}{*}{} \\
\hline \multirow{2}{*}{ Lead } & $20-280 \mu \mathrm{g} /$ day adults & \multirow{2}{*}{} \\
\cline { 2 - 2 } & $10-275 \mu \mathrm{g} /$ day children & \\
\hline Calcium & $1000 \mathrm{mg} / \mathrm{L}$ & {$[34]$} \\
\hline
\end{tabular}

\section{Material and methods}

\subsection{Chemical and reagents}

Standard solutions for different metals were purchased from Fisher Scientific (Bishop Meadow Road Loughborough, UK), and working standard solutions were prepared by simple dilution with distilled water. Sulfuric acid, perchloric acid and nitric acid were all of Analytical grade (BDH, England). All glassware's were of borosilicate and purchased from British Glass (Churchhill way, Sheffield, UK).

\subsection{Instrumentation}

Perkin Elmer flame atomic absorption spectrometer (A Analyst 200) equipped with hollow cathode lamp was used for metals determination. The operating parameters were set as recommended by the manufacturer, slit width, $0.5 \mathrm{~nm}$; current, $10 \mathrm{~mA}$ each with different wavelength as shown in table 2 . The flame composition was air (flow rate, $10 \mathrm{~L} / \mathrm{min}$ ) and acetylene flame (flow rate, $2.5 \mathrm{~L} / \mathrm{min}$ ). The calibration curves were drawn for each element by plotting absorbance versus concentration of each element. Weight measurement was done by using Kern Analytical balance (Kern GmbH, Germany).

\subsection{Sample collection and sample preparation}

Nearly five hundred milliliter of each milk sample was collected in sterilized plastic bottles from Hyderabad and its adjacent areas. Milk of different animal's which include camel (9), sheep (10), goat (10) cow (10) and buffalo (11) and packed milk (10) was collected. Before injecting into AAS each sample was subjected to acid digestion as described by Javed et al 2009 [35]. Briefly, one gram of milk was added to ten millilitre of concentrated nitric acid and heated for twenty minutes. Finally five milliliter of perchloric acid was added and heated vigorously until white fumes appeared 
and volume reduced 2-3 ml. Final volume was adjusted to fifty milliliter by adding distilled water in it. Calcium, lead and cadmium concentration in milk was determined by AAS as described by Licata et al 2004 [2].

\subsection{Statistical analysis}

The data was analyzed by using excel data sheets and SPSS 18. The simple percentage plus mean values + SD of the heavy metals were calculated.

\section{Results and discussion}

\subsection{Method validation}

Calibration curves were developed by plotting absorbance versus concentration of each element, and coefficient of determination for each element was determined and presented in table 2

Table 2 Parameters and method characteristic used for different metals determination

\begin{tabular}{|c|c|c|l|c|l|c|c|}
\hline Metal & Wavelength & $\begin{array}{l}\text { Slit } \\
\text { width }\end{array}$ & $\begin{array}{l}\text { Calibration } \\
\text { equation }\end{array}$ & $\begin{array}{l}\text { Coefficient of } \\
\text { determination }\end{array}$ & Flame & $\begin{array}{l}\text { LOD }^{\mathbf{1}} \\
(\boldsymbol{\mu g} / \mathbf{L})\end{array}$ & $\begin{array}{l}\mathbf{L O Q}^{\mathbf{2}} \\
(\boldsymbol{\mu g} / \mathbf{L})\end{array}$ \\
\hline $\mathrm{Ca}$ & $422.7 \mathrm{~nm}$ & 0.5 & $\mathrm{y}=0.003 \mathrm{x}-0.024$ & 0.986 & Oxy-acetylene & 10 & 30.3 \\
\hline $\mathrm{Cd}$ & $228.8 \mathrm{~nm}$ & 0.5 & $\mathrm{y}=0.001 \mathrm{x}-0.008$ & 0.987 & Oxy-acetylene & 1.5 & 15 \\
\hline $\mathrm{Pb}$ & $217.3 \mathrm{~nm}$ & 0.5 & $\mathrm{y}=0.25 \mathrm{x}+1.5$ & 0.976 & 0xy-acetylene & 1.5 & 15 \\
\hline
\end{tabular}

$$
\begin{gathered}
\text { Limit of detection }\left(L O D=3.3 \times \frac{\sigma}{\text { Slope }}\right. \\
\text { Limit of quantification } L O Q=10 \times \frac{\sigma}{\text { Slope }}
\end{gathered}
$$

Accuracy and precision for each element was determined by external standard addition method and found to be in the range of 95-98\% (Results are not given here). Limit of detection and limit of quantification was determined as described by Shrivastava et al 2011 [36] and given in table 2.

\subsection{Surveillance results}

Calcium, lead and cadmium concentration in milk samples after acid digestion were analyzed by using flame atomic absorption spectroscopy. The mean concentration of metals in milk sample collected from Hyderabad is presented in Table 3.

Nearly all samples were found to be contaminated with lead having mean concentration of $4.3,3.1,2.8,3.0,2.5,6.7 \mu \mathrm{g} / \mathrm{L}$ in goat, cow, buffalo, camel, sheep and packed milk respectively (table 3). Higher concentration of lead was found in packed liquid samples $(6.7 \mu \mathrm{g} / \mathrm{L})$. This higher value of lead might be attributed to extra process of packaging which may contribute to its higher value. Figure 1 shows the box and whisker plot of different metals in milk samples. Form figure it is clear that next higher concentration is found in goat milk samples $4.3 \mu \mathrm{g} / \mathrm{L}$. This higher concentration of lead is due to goat feeding interest. Goat is generally keep grazing in open filed and mostly eat smaller shots and buds which usually contains higher concentration of heavy metals as described by Mahmood et al 2010 [37]

Cadmium was found in twenty samples out of sixty with mean concentration level $1.9 \mu \mathrm{g} / \mathrm{L}$. The same trend of cadmium is also observed for liquid packed milk.

Calcium being as an essential element was found in all samples and highest concentration was found in the camel milk $24 \mu \mathrm{g} / \mathrm{L}$ (Table 3). Calcium content in milk is dependent upon the feeding and animal species, and camel milk have highest amount of calcium as reported by Said Zibaee et al 2015 [38]. 
Table 3 Metals concentration in milk samples of different animals determined by using AAS

\begin{tabular}{|c|c|c|c|c|c|c|c|c|c|c|c|c|}
\hline \multirow[t]{2}{*}{ Metal } & \multicolumn{2}{|c|}{ Goat $(n=10)$} & \multicolumn{2}{|c|}{$\operatorname{Cow}(n=10)$} & \multicolumn{2}{|c|}{ Buffalo $(n=11)$} & \multicolumn{2}{|c|}{ Camel $(n=9)$} & \multicolumn{2}{|c|}{ Sheep $(n=10)$} & \multicolumn{2}{|c|}{ Packed $(n=10)$} \\
\hline & Range & $\begin{array}{l}\text { Mean } \\
(\mu \mathrm{g} / \mathrm{L})\end{array}$ & Range & $\begin{array}{l}\text { Mean } \\
(\mu \mathrm{g} / \mathrm{L})\end{array}$ & Range & $\begin{array}{l}\text { Mean } \\
(\mu \mathrm{g} / \mathrm{L})\end{array}$ & Range & $\begin{array}{l}\text { Mean } \\
(\mu g / L)\end{array}$ & Range & $\begin{array}{l}\text { Mean } \\
(\mu \mathrm{g} / \mathrm{L})\end{array}$ & Range & $\begin{array}{l}\text { Mean } \\
(\mu \mathrm{g} / \mathrm{L})\end{array}$ \\
\hline Cadmium & $1.1-3$ & $1.9 \pm 0.1$ & $1.1-2.8$ & $1.5 \pm 0.1$ & $2.1-3.1$ & $2.2 \pm 0.1$ & $1.1-1.8$ & $1.3 \pm 0.1$ & $1.1-2.1$ & $1.6 \pm 0.1$ & $1.2-2.8$ & $2.0 \pm 0.1$ \\
\hline Lead & $2.9-7.1$ & $4.3 \pm 0.2$ & $2.5-5.1$ & $3.1 \pm 0.2$ & $1.1-4.2$ & $2.8 \pm 0.2$ & $2.1-4.2$ & $3.0 \pm 0.2$ & $1.1-5.2$ & $2.5 \pm 0.2$ & $5.2-8.1$ & $6.7 \pm 0.2$ \\
\hline Calcium & $9-15$ & $12 \pm 0.1$ & $10-17$ & $13.3 \pm 0.1$ & $10-24$ & $18 \pm 0.1$ & $17-28$ & $24 \pm 0.1$ & $8-12$ & $10 \pm 0.1$ & $9-16$ & $12 \pm 0.1$ \\
\hline
\end{tabular}

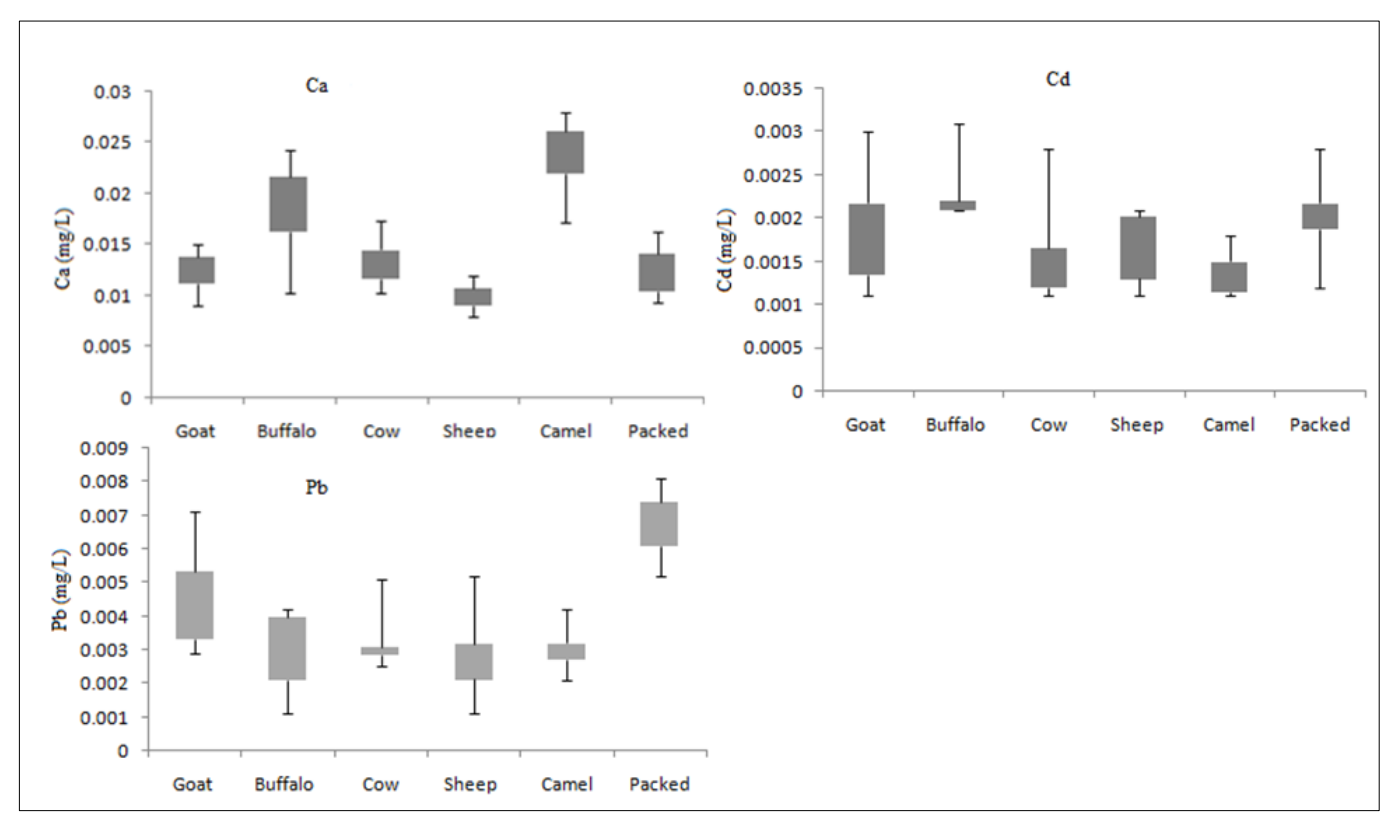

Figure 1 Box and Whisker plot of calcium, cadmium, and lead in different milk samples 
Heavy metals contamination in milk available in Pakistan is much lower, when compared with the allowable limits in milk (Table 1). There is a wide variation in the published data for the elemental concentrations of milk in different countries (Table 4). Most probably level of concentration is dependent upon the sampling point. Some of the results are recorded in table 4 for comparison with the present values. The concentrations of the present study are comparable with the published data. This shows that the milk consumed in Hyderabad region is poor source of $\mathrm{Cd}, \mathrm{Pb}$ and good source of calcium.

Table 4 Comparative study of metal concentration reported in milk

\begin{tabular}{|l|c|c|c|}
\hline \multirow{2}{*}{ Country } & \multicolumn{2}{|l|}{ Heavy metals reported in milk } & \multicolumn{2}{|c|}{} \\
\cline { 2 - 4 } & $\mathbf{P b}(\boldsymbol{\mu g} / \mathbf{L})$ & $\mathbf{C d}(\boldsymbol{\mu g} / \mathbf{L})$ & Reference \\
\hline Turkey & 6.83 & 0.257 & {$[39]$} \\
\hline Taiwan & 2.03 & 0.044 & {$[40]$} \\
\hline Italy & 1.32 & 0.02 & {$[2]$} \\
\hline Croatia & 42.11 & 5.31 & {$[41]$} \\
\hline California & 91 & 6.0 & {$[42]$} \\
\hline Argentine & 25 & 1.47 & {$[43]$} \\
\hline Brazil & 40 & 1000 & {$[44]$} \\
\hline Libya & 3.43 & 1.24 & {$[45]$} \\
\hline Present & 3.14 & 1.9 & \\
\hline
\end{tabular}

\section{Conclusion}

Different milk samples commonly consumed in Hyderabad were analyzed by AAS after simple acid digestion. Camel milk was found to be rich source of calcium, while lead and cadmium (potentially toxic elements) were found in lower quantities than allowable limit of EU and Pakistani standard specification. This indicates that area which investigated in this study is not at risk of environmental pollution. But still strict control of trace and toxic element levels in these foods is therefore advisable.

\section{Compliance with ethical standards}

\section{Acknowledgments}

The authors would like to acknowledge with great thanks to Director of Dr. M.A Kazi institute of chemistry Prof. Dr Mehbob Ali Rind for providing the Research facilities at the institute.

\section{Disclosure of conflict of interest:}

No potential conflict of interest was reported by the authors.

\section{.References}

[1] Ataro A, McCrindle RI, Botha B, McCrindle CME,Ndibewu P. Quantification of trace elements in raw cow's milk by inductively coupled plasma mass spectrometry (ICP-MS). Food Chemistry. 2008; 111(1):243-248.

[2] Licata P, Trombetta D, Cristani M, Giofre F, Martino D, Calo M,Naccari F. Levels of toxic and essential metals in samples of bovine milk from various dairy farms in Calabria, Italy. Environmental International. 2004; 30(1):16.

[3] González-Montaña JR, Senís E, Gutiérrez A and Prieto, F. Cadmium and lead in bovine milk in the mining area of the Caudal River (Spain). Environmental Monitoring and Assessment. 2012; 184(7): 4029-4034.

[4] Tunegova M, Toman R,Tančin V. Heavy metals-environmental contaminants and their occurrence in different types of milk. Slovak Journal of Animal Science. 2016; 49(3): 122-131. 
[5] Kazi TG, Jalbani N, Baig JA, Kandhro GA, Afridi HI, Arain MB, Jamali MK,Shah AQ. Assessment of toxic metals in raw and processed milk samples using electrothermal atomic absorption spectrophotometer. Food and chemical Toxicology. 2009; 47(9): 2163-2169.

[6] Prince RL, Smith M, Dick IM, Price RI, Webb PG, Henderson NK,Harris MM. Prevention of postmenopausal osteoporosis: a comparative study of exercise, calcium supplementation, and hormone-replacement therapy. New England journal of medicine. 1991; 325(17): 1189-1195.

[7] Ismail A, Riaz M, Akhtar S, Goodwill JE, Sun J. Heavy metals in milk: global prevalence and health risk assessment. Toxin Reviews. 2019; 38(1): 1-12.

[8] Pence BC. Role of calcium in colon cancer prevention: experimental and clinical studies. Mutation Research/Fundamental and Molecular Mechanisms of Mutagenesis. 1993; 290(1): 87-95.

[9] Curhan GC, Willett WC, Rimm EB,Stampfer MJ. A prospective study of dietary calcium and other nutrients and the risk of symptomatic kidney stones. New England Journal of Medicine.1993; 328(12): 833-838.

[10] Zheng, N, Wang, Q, Zhang, X, Zheng, D, Zhang, Z. and Zhang, S. Population health risk due to dietary intake of heavy metals in the industrial area of Huludao city, China. Science of the Total Environment. 2007; 387(1): 96-104.

[11] Duruibe J, Ogwuegbu M,Egwurugwu J. Heavy metal pollution and human biotoxic effects. International journal of physical science .2007; 2(5): 112-118.

[12] Malhat F, Hagag M, Saber A. Contamination of cow's milk by heavy metal in Egypt. Bulletin of Environmental Contamiantion and Toxicology. 2012; 88(4): 611-613.

[13] Tripathi R, Raghunath R, Sastry V,Krishnamoorthy T. Daily intake of heavy metals by infants through milk and milk products. Science of Total Environment. 1999; 227(2-3): 229-235.

[14] Phillips C, Győri Z,Kovács B. The effect of adding cadmium and lead alone or in combination to the diet of pigs on their growth, carcase composition and reproduction. Journal of the science of food and agriculture. 2003; 83(13): 1357-1365.

[15] Ozmen 0,Mor F. Acute lead intoxication in cattle housed in an old battery factory. Veterinary and Human Toxicology. 2004; 46(5): 255-256.

[16] Iftikhar B, Arif S, Siddiqui S,Khattak R. Assessment of toxic metals in dairy milk and animal feed in Peshawar, Pakistan. Biotechnology Journal International. 2014; 883-893.

[17] Cai Q, Long M-L, Zhu M, Zhou Q-Z, Zhang L,Liu J. Food chain transfer of cadmium and lead to cattle in a lead-zinc smelter in Guizhou, China. Environmental Pollution. 2009; 157(11): 3078-3082.

[18] Demayo A, Taylor MC, Taylor KW, Hodson PV,Hammond PB. Toxic effects of lead and lead compounds on human health, aquatic life, wildlife plants, and livestock. Critical Reviews in Environmental Science and Technology. 1982; 12(4): 257-305.

[19] Liu J, Goyer RA,Waalkes MP. Toxic effects of metals. Casarett \& Doull's toxicology: The basic science of poisons. 2008; 931-979.

[20] Neal AP,Guilarte TR. Mechanisms of lead and manganese neurotoxicity. Toxicology research. 2013; 2(2): 99-114.

[21] Godt, J, Scheidig F, Grosse-Siestrup C, Esche V, Brandenburg P, Reich A,Groneberg DA. The toxicity of cadmium and resulting hazards for human health. Journal of occupation Medicine and Toxicology. 2006; 1(22): 1-6.

[22] Waalkes MP. Cadmium carcinogenesis in review. Journal of inorganic biochemistry. 2000; 79(1): $241-244$.

[23] Järup L, Berglund M, Elinder CG, Nordberg G,Vanter M. Health effects of cadmium exposure-a review of the literature and a risk estimate. Scandinavian journal of work, environment \& health. 1998; 1-51.

[24] Waseem A, Arshad J, Iqbal F, Sajjad A, Mehmood Z,Murtaza G. Pollution status of Pakistan: a retrospective review on heavy metal contamination of water, soil, and vegetables. BioMed research international. 2014.

[25] Khan S, Rehman S, Khan AZ, Khan MA,Shah MT. Soil and vegetables enrichment with heavy metals from geological sources in Gilgit, northern Pakistan. Ecotoxicology and Environmental Safety. 2010; 73(7): 1820-1827.

[26] Jamali, M, Kazi, T, Arain, M, Afridi, H, Jalbani, N. and Memon, A. Heavy metal contents of vegetables grown in soil, irrigated with mixtures of wastewater and sewage sludge in Pakistan, using ultrasonic-assisted pseudo-digestion. Journal of Agronomy and Crop Science. 2007; 193(3): 218-228. 
[27] Hussain A, Alamzeb S,Begum S. Accumulation of heavy metals in edible parts of vegetables irrigated with waste water and their daily intake to adults and children, District Mardan, Pakistan. Food chemistry. 2013; 136(3): 1515-1523.

[28] Khan SA, Khan L, Hussain I, Marwat KB,Akhtar N. Profile of heavy metals in selected medicinal plants. Pakistan Journal of Weed Science Research. 2008; 14(1-2): 101-110.

[29] Murtaza G, Ghafoor A, Qadir M, Owens G, Aziz M,Zia M. Disposal and use of sewage on agricultural lands in Pakistan: A review. Pedosphere. 2010; 20(1): 23-34.

[30] Qaiser S, Saleemi AR, Mahmood Ahmad, M. Heavy metal uptake by agro based waste materials. Electronic Journal of Biotechnology. 2007; 10(3); 409-416.

[31] Farooq M, Anwar F,Rashid U. Appraisal of heavy metal contents in different vegetables grown in the vicinity of an industrial area. Pakistan Journal of Botany. 2008; 40(5): 2099-2106.

[32] Qadir M, Ghafoor A, MurtazaG,Murtaza G. Cadmium concentration in vegetables grown on urban soils irrigated with untreated municipal sewage. Environment, Development and Sustainability. 2000; 2(1): 13-21.

[33] Raikwar MK, Kumar P, Singh M,Singh A. Toxic effect of heavy metals in livestock health. Veterinary world. 2008; 1(1): 28-30.

[34] Naim Maalouf, M.D. How much calcium is too much? Nutrition 2015: https://utswmed.org/medblog/calcium/

[35] Javed I, Jan I, Muhammad F, Khan MZ, Aslam B,Sultan JI. Heavy metal residues in the milk of cattle and goats during winter season. Bulletin of environmental contamination and toxicology. 2009; 82(5): 616-620.

[36] Shrivastava A,Gupta VB. Methods for the determination of limit of detection and limit of quantitation of the analytical methods. Chronicles of Young Scientists. 2011; 2(1): 21.

[37] Mahmood A,Usman SA. comparative study on the physicochemical parameters of milk samples collected from buffalo, cow, goat and sheep of Gujrat, Pakistan. Pakistan Journal of Nutrition. 2010; 9(12): 1192-1197.

[38] Said Zibaee, Syed Musa al-reza Hosseini, Mahdi Yousefi, Ali Taghipour, Mohammad Ali Kiani, and Mohammad Reza Noras Nutritional and Therapeutic Characteristics of Camel Milk in Children: A Systematic Review Electron Physician. 2015 Nov; 7(7): 1523-1528.

[39] Ay Ü,Karayünlü S. Modification in direct analysis method: metal levels in raw milk at the region of Izmit by graphite furnace atomic absorption spectrophotometer. International journal of food science \& technology. 2008; 43(2): 326-329.

[40] Jeng S, LeeS,Lin S. Determination of cadmium and lead in raw milk by graphite furnace atomic absorption spectrophotometer. Journal of dairy science.1994; 77(4): 945-949.

[41] Sikirić M, Brajenović N, Pavlović I, Havranek J,Plavljanić N. Determination of metals in cow's milk by flame atomic absorption spectrophotometry. Czech Journal of Animal Science. 2003; 48(11): 481-486.

[42] Bruhn J,Franke A. Lead and cadmium in California raw milk. Journal of dairy science. 1976; 59(10):1711-1717.

[43] Rubio M, Sigrist M, Encinas T, Baroni E, Coronel J, Boggio J,Beldomenico H. Cadmium and lead levels in cow's milk from a milking region in Santa Fe, Argentine. Bulletin of environmental contamination and toxicology. 1998; 60(1): 164-167.

[44] Okada IA, Sakuma AM, Maio FD, Dovidauskas S,Zenebon O. Evaluation of lead and cadmium levels in milk due to environmental contamination in the Paraiba Valley region of Southeastern Brazil. Revista de Saúde Pública. 1997; 31(2): 140-143.

[45] Elatrash S,Atoweir N. Determination of lead and cadmium in raw cow's milk by graphite furnace atomic absorption spectroscopy. International Journal of Chemical Sciences.2014; 12(1): 92-100. 